Ks. Arkadiusz Nocoń ${ }^{1}$

\title{
Męczennicy Afryki Pólnocnej w Martyrologium Rzymskim
}

Historycy Kościoła podkreślają zgodnie, że na tereny Afryki Północnej chrześcijaństwo dotarło relatywnie wcześnie, a jego rozwój był tam tak dynamiczny, że porównać go można jedynie z rozwojem chrześcijaństwa w Syrii i w Azji Mniejszej². Ci sami historycy nie potrafią jednak wyjaśnić przyczyn tak gwałtownego wzrostu liczby uczniów Chrystusa na terenie Afryki, uciekając się do ogólnego stwierdzenia, że chrześcijaństwo trafiło tam na „podatny grunt”" Rzeczywiście, jeśli spojrzeć na początki ewangelizacji w Afryce Północnej, nie spotkamy tam Apostołów czy Ojców apostolskich ${ }^{4}$, nie znamy też imion pierwszych misjonarzy ${ }^{5}$. Czyżby zatem jedynym wyjaśnieniem fenomenu afrykańskiego Kościoła była zasada sformułowana przez jednego z jego przedstawicieli - Tertuliana, że nasieniem chrześcijan jest krew męczenników? ${ }^{6}$ Jeśli tak, to ilu ich było? W jakim okresie, w jakich latach i z jakiego powodu ponosili najczęściej męczeństwo? Na te i inne pytania przeciętny katolik, ale również duchowny nie otrzyma podstawowych nawet informacji z Kalendarza liturgicznego i opartego na nim Proprium de sanctis w Mszale Rzymskim i Liturgii

1 Ks. dr Arkadiusz Nocoń, professore invitato na Pontificia Università Gregoriana w Rzymie, pracownik watykańskiej Kongregacji Kultu Bożego i Dyscypliny Sakramentów; e-mail: narcadio@yahoo.it, ORCID: 0000-0002-7513-6071.

2 Por. K. Baus, Le origini, tł. E. Guerriero, w: H. Jedin, Storia della Chiesa, t. 1, Milano 1997, s. 274.

3 Por. Baus, Le origini, s. 273.

4 Niektórzy papieże (np. Innocenty I i Grzegorz Wielki) przypisywali wprawdzie początki chrześcijaństwa w Afryce Północno-Zachodniej św. Piotrowi i jego uczniom, ale nie potwierdzają tego świadectwa historyczne. Por. B. Kumor, Afryka-Kościót katolicki - Starożytność, EK I 141.

5 Por. Baus, Le origini, s. 273.

6 Por. Tertullianus, Apologeticum 50, 13: „Sanguis martyrum, semen christianorum”. 
Godzin, gdzie wspomina się zaledwie o trzech afrykańskich męczennikach z pierwszych wieków: o św. Perpetui i św. Felicycie (7 III) oraz o św. Cyprianie (16 IX). Jest jednak księga liturgiczna, która w jakiś stopniu może uzupełnić naszą wiedzę o męczennikach afrykańskich, a mianowicie Martyrologium Rzymskie. Na podstawie tej właśnie księgi będziemy starali się dowiedzieć, ilu afrykańskich chrześcijan, wyniesionych później do chwały ołtarzy, w jakim czasie, na jakim terenie $i$ w jakich okolicznościach oddało życie za Chrystusa. Na początek jednak kilka słów o samej księdze.

\section{Martyrologium Rzymskie}

Początkowo księga ta zawierała jedynie imiona i krótkie informacje o męczennikach (martyres), a później także o wszystkich innych świętych Kościoła. Zmieniana i uzupełniana na przestrzeni wieków (najstarsze zachowane Martyrologium - Martyrologium syriacum pochodzi z początku $\mathrm{V}$ wieku) ${ }^{7}$ doczekała się najnowszego wydania w 2001 roku jako ostatnia, dwudziesta trzecia księga liturgiczna będąca rezultatem posoborowej (Vaticanum II) odnowy liturgii rzymskiej ${ }^{8}$. Uzupełniona i ponownie wydana w 2004 roku (editio altera) $)^{9}$ zawiera 6652 elogia świętych i błogosławionych, od czasów biblijnego Abla aż po dzień dzisiejszy. Podana cyfra elogiów nie oznacza oczywiście pełnej liczby świętych, a jedynie przypadki kultu zaaprobowane przez Kościół ${ }^{10}$. Charakter tej księgi jest, jak wspomniano, liturgiczny: widać to w budowie samych elogiów łączących w sobie lex orandi et credendi Kościoła ${ }^{11}$, jak i w przeznaczeniu Martyrologium do celebracji liturgicznej mającej na celu uświęcenie człowieka, ale przede wszystkim uwielbienie Boga ${ }^{12}$. W dniu narodzin świętych dla nieba Kościół w pierwszym rzędzie głosi bowiem misterium paschalne Chrystusa, gdyż zarówno w chwili próby, jak i w zwycięstwie świętych objawia się przede wszystkim moc zmartwychwstałego Pana ${ }^{13}$. Liturgiczny charakter Martyrologium nie odmawia mu oczywiście war-

7 Por. B. Nadolski, Leksykon liturgii, Poznań 2006, s. 876.

8 Por. M. Matuszewski, „Martyrologium Romanum” jako księga liturgiczna, „Anamnesis” 45 (2006) s. 45.

9 Por. Martyrologium Romanum, Città del Vaticano 2004 (odtąd stosujemy skrót MR, obok którego podajemy datę, pod którą występuje elogium, jego numer i stronę).

10 Por. Nadolski, Leksykon liturgii, s. 877.

11 Por. Matuszewski, ,,Martyrologium Romanum” jako księga liturgiczna, s. 50.

12 Por. Matuszewski, ,, Martyrologium Romanum” jako księga liturgiczna, s. 48.

13 Por. S. Cichy, Święci w liturgii, ,,Anamnesis” 45 (2006) s. 3. 
tości historycznej: jak powszechnie wiadomo, księga ta w znacznie większym stopniu niż inne księgi liturgiczne zawiera w sobie elementy dokumentalne ${ }^{14}$. Jej ostatnie wydanie zostało przy tym poddane tak szczegółowej analizie historyczno-krytycznej, że słusznie jest ona nazwana „historią Kościoła w wymiarze świętości" ${ }^{15}$. Wszystko to tym śmielej zachęca nas do poszukiwania w Martyrologium informacji na temat męczenników z Afryki Północnej.

\section{Geografia męczeństwa}

Jak już zostało powiedziane, na temat początków chrześcijaństwa na terenie Afryki Północnej brak jest precyzyjnych wiadomości, a pierwszy dokument historyczny, który wspomina o wyznawcach Chrystusa na tych terenach (Akta męczenników scylitańskich) ${ }^{16}$ pochodzi z około 180 roku. W niewiele późniejszych pismach Tertuliana mowa jest już jednak o tak znaczącej obecności uczniów Chrystusa w Afryce ${ }^{17}$, że można wysnuć wniosek, iż chrześcijaństwo musiało tam dotrzeć relatywnie wcześnie i spotkać się z pozytywnym przyjęciem ${ }^{18}$. Przeważa opinia, że było to na pewno w pierwszej połowie II wieku, a być może nawet pod koniec I wieku ${ }^{19}$. Niewykluczone, że pierwsze nawrócenia miały miejsce w społeczności żydowskiej, mocno obecnej w Afryce ${ }^{20}$. Pewne natomiast jest, że chrześcijaństwo dotarło tutaj ze Wschodu ${ }^{21}$ i rozwijało się początkowo w środowisku języka greckiego: w tym języku sprawowane też były pierw-

14 Por. M. Sodi, Martyrologium Romanum. Znaczenie, walor i aktualność ostatniej posoborowej księgi liturgicznej, tł. Z. Adamiak, „Seminare” 25 (2008) s. 12-13.

15 Por. Sodi, Martyrologium Romanum, s. 14. O Martyrologium jako o ważnym źrodle wiadomości o męczennikach pisze również M. Starowieyski. Por. M. Starowieyski, Męczeństwo, w: Męczennicy, opr. E. Wipszycka - M. Starowieyski, OŻ 9, Kraków 1991, s. 120.

16 Acta Scillitanorum, ed. H. Musurillo, The Acts of the Christian Martyrs, Oxford 1972, s. 86-88, tł. A. Bober, OŻ 9, Kraków 1991, s. 240-243.

17 Por. np. Tertullianus, Apologeticum 1, 7.

18 Por. Baus, Le origini, s. 273.

19 Por. J. Daniélou - H. Marrou, Dalle origini a S. Gegorio Magno, tł. G.D. Gordini, w: L.J. Rogier - R. Aubert - M.D. Knowles, Nuova storia della Chiesa, t. 1, Torino 1970, s. 196.

20 Por. Daniélou - Marrou, Dalle origini a S. Gegorio Magno, s. 196.

21 Por. M. Scaduto, Africa: Storia cristiana antica, w: Enciclopedia Cattolica, t. 1, red. M. Scaduto, Firenze 1948, s. 393. 
sze liturgie ${ }^{22}$. Późniejsza organizacja wspólnoty chrześcijańskiej miała już jednak charakter łaciński ${ }^{23}$.

Podobnie jak w innych prowincjach cesarstwa, tak również w Afryce Północnej głoszenie Ewangelii miało miejsce najpierw w miastach, a dopiero później na prowincji ${ }^{24}$. Skuteczność tego przepowiadania musiała być bardzo duża, skoro w III wieku chrześcijaństwo w miastach było już religią większości, obejmującą wszystkie stany ${ }^{25}$. Tak dynamicznemu rozwojowi nie były w stanie przeszkodzić wybuchające co jakiś czas prześladowania, które, jak wiadomo, nie obejmowały jednocześnie całego terytorium cesarstwa, a jedynie poszczególne jego prowincje, a nawet pojedyncze miasta ${ }^{26}$. Jakie prowincje i miasta w Afryce Północnej wspomniane są w Martyrologium? $\mathrm{Na}$ to pytanie chcemy odpowiedzieć w tym rozdziale, wyłączając z naszych poszukiwań jedynie Egipt, który w większości opracowań dotyczących historii Kościoła w Północnej Afryce traktowany jest osobno.

O męczennikach na interesującym nas obszarze Afryki Północnej Martyrologium wspomina w 70 elogiach $^{27}$. Każde z nich, mimo że ze swej natury nie jest notą biograficzną świętego, zaczyna się jednak od podania miejsca jego śmierci. Ponieważ nie wszystkie z tych miejsc mają odpowiedniki w języku polskim, dlatego tam, gdzie było to możliwe, staraliśmy się ustalić i podać obok nazwy łacińskiej współczesne brzmienie tej miejscowości, również z tego powodu, że wiele spośród tych miejsc to obecnie cel wypraw naukowych i turystycznych, ze względu na znajdujące się tam zabytki kultury antycznej. Warto naszym zadaniem przypomnieć, że miejsca te uświęcone również zostały krwią męczenników. Analizując wspomniane elogia, zauważamy, że w 17 spośród nich mowa jest o Afryce ogólnie (in Africa), a z poszczególnych prowincji, poczynając od Wschodu, trzy razy wspomniana jest Libia ${ }^{28}$ : raz w sensie ogólnym (in Libya) ${ }^{29}$, a w dwóch

22 Por. Daniélou - Marrou, Dalle origini a S. Gegorio Magno, s. 196.

23 Scaduto, Africa: Storia cristiana antica, s. 393.

24 Por. J. Grzywaczewski, Chrześcijaństwo na wsi afrykańskiej w okresie patrystycznym, w: Ewangelizacja w epoce patrystycznej. Zagadnienia wybrane, red. F. Drączkowski - J. Pałucki, Lublin 1994, s. 25.

25 Por. Baus, Le origini, s. 483.

26 Por. M. Starowieyski, Z historii wczesnego chrześcijaństwa: Biblia, męczennicy, poganie i inni, Kraków 2015, s. 195.

27 Wszystkie podane przez nas w tym artykule dane liczbowe obarczone są możliwością błędu ze względu na tzw. ręczne liczenie.

28 Po reformie Dioklecjana Libia została podzielona na Libię wschodnią (Libya inferior) i Libię zachodnią (Libya superior). Por. A. di Berardino, Cartine geografiche, DPAC III 99.

29 Por. MR 8 I (2), s. 89. 
przypadkach podane są konkretne jej miejscowości, Pentapolis ${ }^{30}$ i Cyrena (dzisiejsze Szahhat) $^{31}$.

O Afryce Prokonsularnej, obejmującej od czasów Septymiusza Sewera (zm. 211) mniej więcej terytorium współczesnej Tunezji, mowa jest ogólnie jeden raz (in Africa Proconsulari) $)^{32}$, a w 27 przypadkach podane są konkretne miejscowości. Najczęściej, bo 17 razy, wspomina się męczenników z Kartaginy ${ }^{33}$ (w dwóch przypadkach, co jest absolutnym wyjątkiem w Martyrologium, podano także nazwę ulicy i tytuł bazyliki, w której spoczywają męczennicy) $)^{34}$. Z innych miejscowości w Afryce Prokonsularnej wymieniona jest Avensa (dziś w pobliżu Bordj-Hamdouna) $)^{35}$, Thuburbo (dziś Tebourba) ${ }^{36}$, dwa razy Utyka (dziś w pobliżu Henchir-bou-Chateur) ${ }^{37}$, Uzalis (dziś El Alia) ${ }^{38}$, Voli (dziś trudne do zidentyfikowania) ${ }^{39}$, Maxula Prates (dziś Rades) ${ }^{40}$ oraz cztery miejscowości, które od końca III wieku będą wchodziły w skład nowej prowincji rzymskiej - Byzaceny ${ }^{41}$. Są to Capsa (dziś Gafsa) ${ }^{42}$, Hadrumentum (dziś Susa) ${ }^{43}$, Colonia Sufetana (dziś Sbeitla) ${ }^{44}$ i Nepte $(\text { dziś Nefta })^{45}$.

30 Por. MR 7 IV (4), s. 224. Pentapolis, czyli związek pięciu największych miast w libijskiej Cyrenajce, tworzyły Cyrena (dziś Szahhat), Apollonia (dziś Minaa Susa), Teuchira - Arsinoe (dziś Tukra), Euhesperides - Berenice (dziś Benghazi) i Barka (dziś El-Marj) zastąpiona z czasem przez Ptolemais (dziś Tolmeita). Por. M. Landau, Na grobie Achillesa, „Wprost” 35 (2004) s. 72.

31 Por. MR 5 VII (3), s. 370.

32 Por. MR 17 V (4), s. 289.

33 Por. MR 18 I (1), s. 104; 25 I (4), s. 116; 3 II (4), s. 131; 12 II (1), s. 146; 7 III (1), s. 179; 7 III (2), s. 179; 23 III (3), s. 202; 23 V (1), s. 299; 27 VI (2), s. 356; 2 VII (2), s. 365; 15 VII (3), s. 390; 15 VII (4), s. 390; 17 VII (1), s. 395; 13 IX (6), s. 513; 14 IX (3), s. $514 ; 29$ X (1), s. 595; 29 XII (4), s. 691.

34 Por. MR 15 VII (3), s. 390 i 15 VII (4), s. 390.

35 Por. MR 15 XII (1), s. 673.

36 Por. MR 30 VII (4), s. 423.

37 Por. MR 18 VIII (2), s. 461; 21 VIII (4), s. 468.

38 Por. MR 16 V (1), s. 287.

39 Por. MR 17 X (4), s. 576.

40 Por. MR 22 VII (3), s. 405.

41 Stolicą tej prowincji było Hadrumetum (dzisiejsza Susa), drugie po Kartaginie najważniejsze miasto w Afryce rzymskiej.

42 Por. MR 2 V (4), s. 266. Miejscowość Capsa wchodziła wcześniej w skład prowincji Numidii i tak została zapisana w MR.

43 Por. MR 11 V (1), s. 280.

44 Por. MR 30 VIII (2), s. 485.

45 Por. MR 6 IX (3), s. 499. 
O męczennikach z Numidii, rzymskiej prowincji oddzielonej od Afryki Prokonsularnej pod koniec II wieku i obejmującej terytorium dzisiejszej północno-wschodniej Algierii, Martyrologium wspomina ogólnie (in Numidia) 2 razy ${ }^{46}$, a w 7 przypadkach podaje konkretne miejscowości. I tak 2 razy pojawia się Hippona (dziś Annaba) ${ }^{47}$, dwa razy Theveste (dziś Tebessa) $^{48}$, a jeden raz Cyrta (dziś Konstantyna) ${ }^{49}$, Lambaesia (dziś Tazoult) ${ }^{50}$ i Thinisa (dziś El Kala) $)^{51}$.

Obszar Mauretanii podzielony został za panowania cesarza Klaudiusza na dwie odrębne prowincje: Mauretanię Caesariensis, odpowiadającą terytorium dzisiejszej Algierii centralnej i zachodniej, oraz Mauretanię Tingitanę, obejmującą obszar dzisiejszego północnego Maroka. Ogólnie o całej Mauretanii (in Mauretania) wspomina się w Martyrologium dwa razy $^{52}$, a w jedenastu elogiach mowa jest o konkretnych miejscowościach. I tak 5 razy wspomniana jest tamtejsza Cezarea (dziś Cherchell) ${ }^{53}$, dwa razy Tingis (dziś Tanger) ${ }^{54}$ i po jednym razie Tigava (dziś El Kherba) ${ }^{55}$, Lemellefa (dziś Bordj-Redir) ${ }^{56}$, Regiae (dziś Arbal) ${ }^{57}$ i Pamaria (dziś trudna do zidentyfikowania) $)^{58}$.

Przedstawiając geografię męczeństwa w Afryce Północnej, należy pamiętać, że granice jej prowincji podlegały częstym zmianom, stąd mogło się zdarzyć, że ta sama miejscowość na przestrzeni wieków należała do różnych prowincji. Gdyby chcieć natomiast zaznaczyć miejsca męczeństwa na współczesnej mapie, to najwięcej z ich znalazłoby się na terenie dzisiejszej Tunezji (11), przy czym jedno tylko z jej miast - Kartagina wspomniane jest w Martyrologium aż 17 razy. Drugim współczesnym państwem z największą ilością miejsc męczeństwa (10) byłaby Algieria, w której sama tylko Cezarea (dziś Cherchell) wspomniana jest w Martyrologium 5 razy. Dwa miejsca męczeństwa moglibyśmy zidentyfikować na terenie dzisiej-

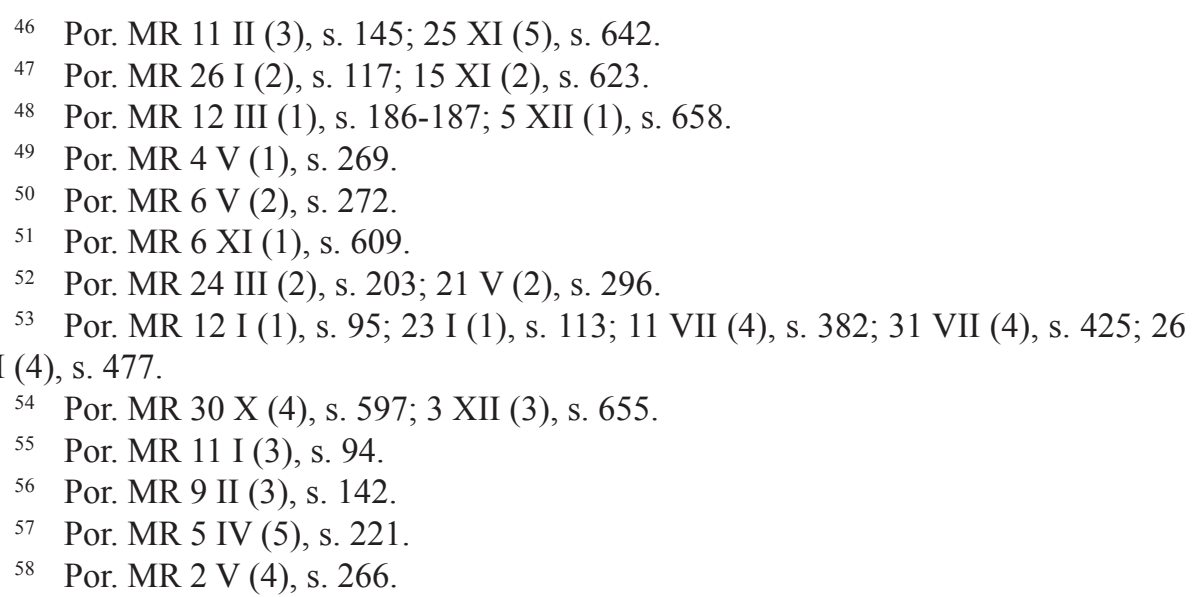


szej Libii: Pentapolis i Cyrenę (dzisiejsze Szahhat) i jedno na terenie dzisiejszego Maroka, tzn. Tingis (dziś Tanger).

\section{Czas męczeństwa}

Każde elogium zaczyna się, jak wspomnieliśmy, od podania miejsca męczeństwa, nie uwzględnia jednak daty, którą, tam gdzie było to możliwe, redaktorzy zamieścili $\mathrm{w}$ indeksie. Nie oznacza to oczywiście, że elogia pozbawione są informacji pozwalających chociażby w przybliżeniu ustalić czas śmierci danego świętego. W przypadku męczenników z Afryki Północnej jest to najczęściej okres panowania cesarza lub prokonsula. Najwcześniejszym z cesarzy, którego wymienia Martyrologium, jest Septymiusz Sewer (193-211). To w czasie jego panowania w Kartaginie zginęły dwie święte męczennice Perpetua i Felicyta (7 III 203) ${ }^{59}$. Kolejnym w porządku chronologicznym jest cesarz Decjusz (249-251), wspomniany w Martyrologium w czterech elogiach ${ }^{60}$, a następnym cesarz Walerian (253260), wspomniany w trzech elogiach ${ }^{61}$. To za panowania tego ostatniego poniósł śmierć męczeńską w Kartaginie m.in. św. Cyprian (14 IX 258) ${ }^{62}$. Najwięcej, bo 5 elogiów, wspomina cesarza Dioklecjana (284-305) ${ }^{63}$, a tylko jedno elogium ostatniego w porządku chronologicznym cesarza Konstansa (337-350) ${ }^{64}$. Z rzymskich prokonsuli w Afryce Północnej wymienieni są Rufin ${ }^{65}$, sprawujący władzę za Septymiusza Sewera, i Anulin ${ }^{66}$, z czasów Dioklecjana.

59 Por. MR 7 III (1), s. 179 i 807.

60 Por. MR 18 I (1), s. 104; 10 IV (1), s. 228; 19 IV (1), s. 243; 6 V (2), s. 272. O prześladowaniach chrześcijan za cesarza Decjusza, zob. E. Wipszycka, Prześladowania w Państwie Rzymskim, w: Męczennicy, opr. E. Wipszycka - M. Starowieyski, OŻ 9, Kraków 1991, s. 40-44.

${ }_{61}$ Por. MR 4 V (1), s. 269; 23 V (1), s. 299; 14 IX (3), s. 514 i 727. O prześladowaniach chrześcijan za cesarza Waleriana, zob. E. Wipszycka, Prześladowania w Państwie Rzymskim, w: Męczennicy, opr. E. Wipszycka - M. Starowieyski, OŻ 9, Kraków 1991, s. 44-46.

${ }^{62}$ Por. MR 14 IX (3), s. 514 i 727.

63 Por. MR 11 II (3), s. 145; 12 II (1), s. 146; 5 VII (3), s. 370; 30 VII (4), s. 423; 5 XII (1), s. 658. O prześladowaniach chrześcijan za cesarza Dioklecjana, zob. E. Wipszycka, Prześladowania w Państwie Rzymskim, w: Męczennicy, opr. E. Wipszycka - M. Starowieyski, OŻ 9, Kraków 1991, s. 47-50.

\footnotetext{
64 Por. MR 25 XI (5), s. 642.

65 Por. MR 27 VI (2), s. 356.

66 Por. MR 15 VII (3), s. 390.
} 
Okres męczeństwa w Afryce nie skończył się z chwilą, gdy chrześcijaństwo stało się religią państwową w czasach cesarza Teodozjusza (379-395), bo już za panowania ariańskiego króla Wandalów Genzeryka (428-477) Martyrologium odnotowuje cały szereg przypadków męczeństwa tych, którzy trwali przy prawdziwej wierze ${ }^{67}$. Podobnie było w czasach drugiego władcy państwa Wandalów Huneryka (477-484), również arianina, który podobnie jak ojciec Genzeryk prześladował katolików w Afryce. Martyrologium wspomina o tym w 7 elogiach $^{68}$. Jeden raz mowa jest także o uzurpatorze Heraklianie (zm. 413), który wystąpił przeciw władzy cesarza Honoriusza (395-423): to za jego panowania donatyści zamordowali św. Marcelina, który „bronił wiary katolickiej"69. Te ostatnie informacje mogą być dla nas o tyle interesujące, że w niektórych publikacjach pojawiają się sugestie, jakoby to represyjna polityka Kościoła i państwa, zwłaszcza wobec donatystów, była powodem niechęci ludności afrykańskiej wobec katolicyzmu, co zaowocowało całkowitym upadkiem chrześcijaństwa w Afryce po inwazji muzułmańskiej ${ }^{70}$. Martyrologium Rzymskie przypomina tymczasem, że zarówno arianie, jak i donatyści nie poprzestawali jedynie na pokojowym głoszeniu swoich nauk, ale dopuszczali się czasem zbrodni. Na podstawie informacji zawartych w elogiach możemy zatem stwierdzić, że na przestrzeni dwustu lat (180-380) przez Północną Afrykę przetoczyło się przynajmniej 5 fal represji wobec chrześcijan i katolików.

\section{Liczba męczenników, płeć i status społeczny}

W bardzo wielu spośród 70 elogiów poświęconych męczennikom afrykańskim używa się terminów mało precyzyjnych, niepozwalających określić dokładnej ich liczby, jak np. plurimi ${ }^{71}$, reliqui ${ }^{72}$, multi $a_{l i i^{73}}$. Czasem, przez zastosowanie jakiegoś porównania, możemy mieć

${ }_{67}$ Por. MR 29 III (3), s. 210; 5 IV (5), s. 221; 16 X (5), s. 573-574; 13 XI (4), s. 620; 28 XI (2), s. 647; 15 XII (1), s. 673.

68 Por. MR 23 III (3), s. 202; 2 V (4), s. 266; 2 VII (2), s. 365; 6 IX (3), s. 499; 12 X (3), s. 567; 6 XII (3), s. 660; 16 XII (2), s. 674.

69 Por. MR 13 IX (6), s. 513.

70 Por. np. H. von Campenhausen, Ojcowie Kościoła, tł. K. Wierszyłowski, Warszawa 1998, s. 394-395.

71 Por. np. MR 16 XII (2), s. 674.

72 Por. np. MR 15 VII (4), s. 390.

73 Por. np. MR 6 V (2), s. 272. 
przynajmniej ogólne wyobrażenie o ich liczbie, jak w przypadku męczenników z Utyki, o których napisano, że ,byli liczniejsi od ryb złowionych przez Apostołów w sieci" "74, czyli było ich z pewnością więcej więcej niż 153 , bo taką liczbę złowionych ryb podaje ewangelista ${ }^{75}$. W dwóch przypadkach dotyczących grup męczenników podano dokładną ich liczbę: 60 z Afryki Byzaceńskiej (dziś Sbeitla w Tunezji) ${ }^{76}$ i 4966 katolików afrykańskich, którzy w 483 roku za panowania Huneryka zostali deportowani z państwa Wandalów i zesłani na Pustynię Libijską ${ }^{77}$. Większość z nich zginęła w czasie drogi, a pozostali zostali zamęczeni na pustyni (trudno w tym miejscu nie pomyśleć o podobnym ludobójstwie, na znacznie większą, niestety, skalę - setek tysięcy Ormian wypędzonych w 1915 roku na Pustynię Syryjską, gdzie zginęli z braku wody i od promieni słońca). Próbując policzyć tylko tych wymienionych w Martyrologium z imienia czy profesji, otrzymaliśmy liczbę 320 męczenników, ogólnie zaś, podsumowując wszystkich, liczba ta wynosi 5303 męczenników afrykańskich z pierwszych wieków. Dodając do nich tych, o których napisano „liczni”, „wielu”, „pozostali”, oraz tych, którzy ponieśli śmierć dla Chrystusa, a nie zostali oficjalnie zaliczeni do grona świętych, moglibyśmy powtórzyć retoryczne pytanie św. Augustyna: „czyż Afryka również nie jest pełna ciał świętych męczenników?"78.

Jeśli chodzi o stan i status społeczny owych 320 męczenników najlepiej opisanych w Martyrologium, to mamy wśród nich 20 biskupów ${ }^{79}$ i 1 prezbitera ${ }^{80}$, co pośrednio potwierdzałoby opinię o episkopalnym charakterze Kościoła afrykańskiego ${ }^{81}$. Mamy też 8 diakonów ${ }^{82}$, 2 subdiako-

74 Por. MR 18 VIII (2), s. 461.

75 Por. J 21,11.

76 Por. MR 30 VIII (2), s. 485.

77 Por. MR 12 X (3), s. 567 i 727.

78 Augustinus, Epistula 78, 3, tł. A. Eckmann, Kult męczenników afrykańskich $w$ pismach św. Augustyna, „Vox Patrum”30/55 (2010) s. 183.

79 Por. MR 18 I (1), s. 104; 7 IV (4), s. 224; 2 V (4), s. 266; 4 V (1), s. 269; 15 VII (3), s. 390; 21 VIII (4), s. 468; 6 IX (3), s. 499; 14 IX (3), s. 514; 12 X (3), s. 567; 15 XI (2), s. 632; 25 XI (5), s. 642; 13 XI (4), s. 620; 28 XI (2), s. 647; 15 XII (1), s. 673; 29 XII (4), s. 691.

${ }^{80}$ Por. MR 12 II (1), s. 146.

81 Por. J. Strzelczyk, Wandalowie i ich afrykańskie państwo, w: https://www.religie.424.pl/articles.php?lng=pl\&pg=3342\&prt=2 (dostęp: 26.04.2019).

82 Por. MR 8 I (2). s. 89; 9 II (3), s. 142; 7 IV (4), s. 224; 6 V (2), s. 272; 21 V (2), s. 296; 2 VII (2), s. 365; 15 VII (4), s. 390. 
nów ${ }^{83}, 1$ opata $^{84}, 2$ mnichów ${ }^{85}, 10$ lektorów $^{86}, 8$ dziewic ${ }^{87}$ i 2 katechumenów ${ }^{88}$.

Spośród ludzi świeckich Martyrologium wymienia jedną babcię ${ }^{89}$, pięć matek $^{90}$, dwóch małżonków ${ }^{91}$ i sześcioro dzieci ${ }^{92}$. Z zawodów znajdujemy tutaj przedstawicieli wojska ${ }^{93}$, kupców ${ }^{94}$ i jednego lekarza ${ }^{95}$. Mamy też wysoko postawionych urzędników państwowych: prokonsula ${ }^{96}$ i trybuna ${ }^{97}$, ale także niewolników ${ }^{98}$, co potwierdza tezę, że chrześcijaństwo obejmowało wszystkie grupy społeczne i wszystkie stany.

\section{Powody męczeństwa}

Przedstawiając powody męczeńskiej śmierci chrześcijan w Afryce, Martyrologium odwołuje się często do ogólnych stwierdzeń typu „za wiarę chrześcijańską" (pro fide christiana) ${ }^{99}$ lub ,za wiarę katolicką" (pro fide catholica) ${ }^{100}$. Nie brak też oczywiście podania bardziej dokładnych powodów męczeństwa, wśród których przeważa odmówienie złożenia ofiary bogom ${ }^{101}$ lub odmówienie oddania boskiej czci

83 Por. MR 2 VII (2), s. 365.

84 Por. MR 2 VII (2), s. 365.

85 Por. MR 2 VII (2), s. 365.

86 Por. MR 12 II (1), s. 146; 3 II (4), s. 131; 7 IV (4), s. 224; 6 V (2), s. 272.

87 Por. MR 12 II (1), s. 146; 5 IV (5), s. 221; 4 V (1), s. 269; 17 V (4), s. 289 ; 11 VII (4), s. 382; 30 VII (4), s. 423.

${ }_{88}$ Por. MR 7 III (1), s. 179. O tym, że było ich dwóch, wiadomo jednak z innych źródeł.

89 Por. MR 3 II (4), s. 131.

90 Por. MR 7 III (1), s. 179; 4 V (1), s. 269; 5 XII (1), s. 658; 6 XII (3), s. 660.

91 Por. MR 23 I (1), s. 113.

92 Por. MR 4 V (1), s. 269; MR 30 VII (4), s. 423.

93 Por. MR 11 I (3), s. 94; 3 II (4), s. 131; 12 III (1), s. 186-187; 4 V (1), s. 269; 30 X (4), s. 597.

94 Por. MR 23 III (3), s. 202.

95 Por. MR 6 XII (3), s. 660.

96 Por. MR 23 III (3), s. 202.

97 Por. MR 13 IX (6), s. 513.

98 Por. MR 7 III (1), s. 179; 16 X (5), s. 573-574.

99 Por. MR 10 IV (1), s. 228; 23 V (1), s. 299.

100 Por. MR 13 IX (6), s. 513; 16 X (5), s. 573-574; 28 XI (2), s. 647; 2 VII (2), s. 365; 6 XII (3), s. 660.

101 Por. MR 11 I (3), s. 94; 12 I (1), s. 95; 5 VII (3), s. 370; 30 VII (4), s. 423; 5 XII (1), s. 658 . 
cesarzowi ${ }^{102}$. Swój sprzeciw wobec pogańskiego kultu chrześcijanie w Afryce wyrażali też czasem w sposób gwałtowny, jak owi mieszkańcy Byzaceny, którzy zniszczyli posąg Hermesa, za co zostali zabici przez rozwścieczonych pogan ${ }^{103}$.

Powszechnie znany jest powód śmierci męczenników z Abiteny, którzy wbrew zakazowi władcy zgromadzili się na niedzielnej liturgii ${ }^{104}$, ale znacznie mniej znany powód męczeńskiej śmierci dwóch diakonów (Pryma i Donata), którzy zostali zabici przez heretyków za to, że bronili ołtarza w kościele ${ }^{105}$, czy męczenników z Numidii, którzy wbrew edyktowi cesarskiemu odmówili wydania świętych ksiąg ${ }^{106}$. Warto podkreślić to przywiązanie chrześcijan w Afryce do przedmiotów związanych z kultem, bo na przykład św. Feliks, biskup, wolał ponieść śmierć niż z rozkazu prokonsula spalić święte księgi ${ }^{107}$, a biskup Walerian zginął, bo odmówił wydania naczyń liturgicznych ${ }^{108}$. Męczennicy związani z wojskiem ginęli z kolei, gdy tak jak św. Maksymilian odmówili złożenia przysięgi wojskowej ${ }^{109}$ lub tak jak św. Fabiusz odmówili niesienia sztandarów namiestnikowskich ${ }^{110}$.

Nauka chrześcijańska, jak możemy przekonać się z tych świadectw, była więc traktowana przez nawróconych mieszkańców Afryki z całą powagą i w sposób integralny, bez rozróżniania na to, co istotne i mniej istotne $\mathrm{w}$ wierze, bez kompromisów $\mathrm{z}$ ówczesną władzą czy panującą religią.

\section{Rodzaje męczeńskiej śmierci}

Martyrologium jako księga liturgiczna nie jest tym samym co passio opisujące dokładnie mękę i śmierć męczennika. W lakonicznych elogiach Martyrologium nie znajdziemy na ten temat zbyt wiele, ale i z tego, co zostało przekazane, można by napisać traktat o ludzkim bestialstwie. $\mathrm{Z}$ naszych ogólnych tylko obliczeń wynika, że chrześcijanie w Afryce

\footnotetext{
102 Por. MR 17 VII (1), s. 395.

103 Por. MR 30 VIII (2), s. 485.

104 Por. MR 12 II (1), s. 146.

105 Por. MR 9 II (3), s. 142.

106 Por. MR 11 II (3), s. 145.

107 Por. MR 15 VII (3), s. 390.

108 Por. MR 15 XII (1), s. 673.

109 Por. MR 12 III (1), s. 186-187.

110 Por. MR 31 VII (4), s. 425.
} 
skazywani byli najczęściej na cztery rodzaje śmierci: ukrzyżowanie ${ }^{111}$, ścięcie ${ }^{112}$, spalenie ${ }^{113}$ i pożarcie przez dzikie zwierzęta ${ }^{114}$. Nie brak było jednak i innych rodzajów śmierci, takich jak: śmierć głodowa ${ }^{115}$, wypędzenie na pustynięę16, strącenie ze skały ${ }^{117}$ czy rozbijcie czaszki ${ }^{118}$. W większości przepadków każdy z tych rodzajów śmierci poprzedzony był okrutnymi torturami (crudeles supplicia) ${ }^{119}$, takimi jak: rozszarpywanie $^{120}$, kaleczenie ostrymi skorupami ${ }^{121}$, dręczenie na „koniku” tortur (eculeus $)^{122}$, przybijanie gwoźdźmi ${ }^{123}$, podpalanie ${ }^{124}$, przypiekanie rozpalonymi blachami ${ }^{125}$.

Po wyliczeniu, pobieżnym tylko, wszystkich tych okropności naturalną rzeczą jest zapytać o zachowanie chrześcijan w obliczu cierpienia i śmierci.

\section{Postawa w obliczu śmierci}

Martyrologium Romanum nazywane jest czasem „Księgą zwycięzców"126, zawiera bowiem imiona tych, którzy mocą łaski Bożej,

111 Por. MR 26 VIII (4), s. 477.

112 Por. MR 11 I (3), s. 94; 7 III (2), s. 179; 5 IV (5), s. 221; 2 V (4), s. 266; 27 VI (2), s. $356 ; 15$ VII (3), s. 390; 17 VII (1), s. 395; 14 IX (3), s. 514; 30 X (4), s. 597.

113 Por. MR 8 I (2), s. 89; 23 I (1), s. 113; 22 V (2), s. 297; 2 VIII (3), s. 430; 6 IX (3), s. 499.

114 Por. MR 7 III (1), s. 179; 11 V (1), s. 280; 11 VII (4), s. 382.

115 Por. MR 19 IV (1), s. 243.

116 Por. MR 12 X (3), s. 567.

117 Por. MR 25 XI (5), s. 642.

118 Por. MR 2 VII (2), s. 365.

119 Por. MR 12 I (1), s. 95; 3 II (4), s. 131; 11 II (3), s. 145.

120 Por. MR 8 I (2), s. 89; 27 VI (2), s. 356; 16 X (5), s. 573-574.

121 Por. MR 8 I (2), s. 89.

122 Por. MR 27 VI (2), s. 356. „Konik” (łac. eculeus) - dosł. ‘źrebię’, w ówczesnym języku więziennym również przyrząd do stosowania tortur. Por. Wipszycka, Prześladowania w Państwie Rzymskim, s. 66: „Szczególnie okrutną torturę stanowił tak zwany koń: odartych z szat więźniów przymocowywano do belki na nóżkach (czegoś w rodzaju naszego „konia” gimnastycznego), a ich członki rozciągano w różne strony przy pomocy lin poruszanych wielokrążkami. Powodowało to wyłamanie kości ze stawów".

123 Por. MR 2 VII (2), s. 365.

124 Por. MR 2 VII (2), s. 365.

125 Por. MR 16 XII (2), s. 674.

126 Por. np. Matuszewski, „Martyrologium Romanum” jako księga liturgiczna, s. 50. 
przechodząc przez najtrudniejsze próby, pozostali wierni Chrystusowi. Myliłby się jednak ten, kto by uważał, że usunięto z tej księgi wszelkie przejawy ludzkiej słabości. I rzecz dotyczy nie tylko młodego Majoryka, syna Dionizji, który w czasie prześladowania wandalskiego bał się tortur, jednak umocniony krzepiącymi słowami matki i jej spojrzeniem okazał się silniejszy od innych i wśród cierpień oddał duszę Bogu ${ }^{127}$.

Św. Rutyliusz, wspominany 2 sierpnia, był już człowiekiem dorosłym, ale i on tak bał się prześladowań, że nie tylko uciekał przed grożącym mu niebezpieczeństwem, ale i niekiedy wykupywał się pieniędzmi, jednak gdy w końcu go pojmano i poddano licznym torturom, nie tylko nie wyparł się Chrystusa, ale i zakończył życie „wspaniałym męczeństwem” (egregio

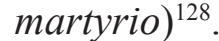

Znaczenie więcej jest oczywiście przykładów bohaterskiej postawy chrześcijan od początku do końca, jak w przypadku znanych męczennic z Kartaginy: Perpetuy i Felicyty. Ta ostatnia, jak podaje Martyrologium, była ciężarna i jej egzekucję zgodnie $\mathrm{z}$ prawem odłożono do czasu, aż porodzi, jednak nawet $\mathrm{w}$ bólach rodzenia potrafiła cieszyć się, że została skazana na śmierć od dzikich zwierząt. Gdy zaś razem z Perpetuą szły z więzienia do amfiteatru, miały tak radosny wyraz twarzy, jakby prowadzono je do nieba ${ }^{129}$. W tej samej Kartaginie zginęli też Satyr, Saturnin, Rewokat i Sekundyn, o których napisano, że ,umierali, obejmując się w braterskim uścisku"130.

O wielu innych, których poddawano najbardziej wyszukanym torturom, jak choćby o opacie Liberacie i jego towarzyszach, wspominanych drugiego lipca, napisano jedynie krótko, ale jakże wymownie, że stoczyli „wspaniałą walkę (speciosum certamen) i otrzymali wieniec od Pana"131. Należy też tutaj wspomnieć męczenników scyllitańskich, którzy, gdy skazano ich na śmierć, klęcząc w miejscu kaźni, jednomyślnie składali dzięki Chrystusowi ${ }^{132}$.

Jak możemy więc zauważyć, Martyrologium ukazuje nam świętych, ale zarazem prawdziwych ludzi, którzy, owszem, mieli swoje lęki, ale w decydującym momencie potrafili wznieść się ponad ludzką słabość.

\footnotetext{
127 Por. MR 6 XII (3), s. 660.

128 Por. MR 2 VIII (3), s. 430.

129 Por. MR 7 III (1), s. 179.

130 Por. MR 7 III (2), s. 179.

131 Por. MR 2 VII (2), s. 365.

132 Por. MR 17 VII (1), s. 395
} 


\section{Podsumowanie}

W posynodalnej adhortacji apostolskiej papieża Jana Pawła II pt. Ecclesia in Africa przypomina się m.in. o tym, że

Ewangelia została rozpowszechniona w Afryce w kilku fazach. Pierwsze wieki chrześcijaństwa były czasem ewangelizacji Egiptu i Afryki Północnej [Adhortacja, jak widzimy, również rozdziela te dwa obszary]. Druga faza, obejmująca regiony kontynentu położone na południe od Sahary, przypadła na XV i XVI stulecie. Faza trzecia, okres niezwykłego wysiłku misyjnego, rozpoczęła się w XIX wieku ${ }^{133}$.

Każda $\mathrm{z}$ tych faz, jak wiadomo, wydała tak wielu męczenników, że nawiązując do słynnej grupy z Utyki (Massa Candida) z III wieku ${ }^{134}$, możemy mówić o Massa Nigra ${ }^{135}$ w każdej z tych epok. W naszych badaniach zajęliśmy się męczennikami z pierwszej fazy ewangelizacji Afryki nie tylko dlatego, że problem męczeństwa jest kluczowy dla zrozumienia starożytności chrześcijańskiej, ale również dlatego, że jest on mało obecny w publikacjach historycznych w naszym kraju ${ }^{136}$. Dotyczy to zagadnienia męczeństwa w starożytności w ogóle, a zwłaszcza na terenie Afryki Północnej, zaskakującej przecież badaczy swym dynamizmem ewangelizacyjnym, porównywalnym jedynie z tym w Syrii i w Azji Mniejszej, zaskakującej liczbą tamtejszych biskupstw (ok. 700 w VI wieku), ustępującą może jedynie Italii, i zaskakującej niezwykle rozwiniętą instytucją synodów (około $60 \mathrm{w}$ latach 312-427). Tym bardziej naglące wydaje się więc uzupełnienie naszej wiedzy o męczennikach w Afryce, o których wciąż, niestety, bardzo mało wiemy i nie dotyczy to tylko najczęściej stawianego pytania o ich liczbę, ale również takich kwestii, jak obszar prześladowania, czas i powody męczeństwa ${ }^{137}$. W ramach jednego artykułu nie sposób oczywiście odpowiedzieć $\mathrm{w}$ pełni na wszystkie te zagadnienia, dlatego zajęliśmy się tylko jednym ze źródeł, a mianowicie Martyrologium Romanum, które, mimo że jest księgą liturgiczną, może jednak uzupełnić naszą wiedzę o historii. W wyniku naszych badań udało nam się, myślę, chociaż trochę pogłębić

133 Jan Paweł II, Ecclesia in Africa 30, cytat za: https://opoka.org.pl/biblioteka/W/ WP/jan_pawel_ii/adhortacje/ecclesia_africa.html (dostęp: 26.04.2019). Więcej na temat ewangelizacji kontynentu afrykańskiego w: Z. Majcher, Historia ewangelizacji kontynentu afrykańskiego $w$ zarysie, ,Seminare” 17 (2001) s. 449-475.

134 Por. MR 18 VIII (2), s. 461.

135 Por. A. Duval, „Massa Nigra”. Męczennicy Czarnej Afryki, tł. P. Mikulska, „Ethos” 53-54 (2001) s. 180-181.

136 Por. Starowieyski, Z historii wczesnego chrześcijaństwa, s. 195.

137 Por. Starowieyski, Z historii wczesnego chrześcijaństwa, s. 196. 
naszą wiedzę o męczennikach Afryki Północnej, uzyskując przynajmniej jakąś ogólną wiedzę o latach prześladowań, miastach, w których miały one miejsce, o liczbie męczenników i ich statusie społecznym, a przede wszystkim o postawie męczenników w obliczu okrutnej najczęściej śmierci.

Byłoby dobrze, aby wszystkie te uzyskane przez nas wiadomości służyły jednak nie tylko zaspokojeniu historycznej ciekawości, ale zgodnie z liturgicznym przeznaczeniem Martyrologium do czytania w chórze i poza chórem ${ }^{138}$, przy różnych okazjach w zależności od rodzaju wspólnoty (np. w kleryckim seminarium czy podczas kapłańskich rekolekcji) ${ }^{139}$, służyły one, owszem, zbudowaniu słuchaczy, ale przede wszystkim uwielbieniu Boga, który „w męczeństwie świętych ukazał cuda swojej łaski, oni bowiem naśladując Chrystusa, przelali krew ku Jego chwale" (z Prefacji o świętych męczennikach).

\section{The Martyrs of North Africa in the Roman Martyrology}

(summary)

As is commonly known, Christianity reached the territories of North Africa relatively early, and its development was so dynamic that it surprises historians. In seeking an explanation of this phenomenon, many point to the line of one of its representatives, Tertullian: "the blood of the martyrs is the seed of Christians". If that was the case, how many martyrs were there in the African Church? In which period and for what reason were they killed? Answers to these and other questions were searched for in the Roman Martyrology, a book that essentially is liturgical, but also contain some documentary elements. This study has led to a deepening of our knowledge of the martyrs of North Africa as it gave some at least general information about the time of the persecutions, the cities in which they took place, the numbers of the martyrs, their social status, and above all about their attitude in the face of death that in most cases was cruel. This information is precious, not only because martyrdom is a key factor for the understanding of Christian antiquity, but also because it is rarely mentioned in historical publications of our country.

Keywords: North Africa; Roman Martyrology; martyrs

\section{Męczennicy Afryki Północnej w Martyrologium Rzymskim}

(streszczenie)

Jak powszechnie wiadomo, chrześcijaństwo dotarło na tereny Afryki Północnej relatywnie wcześnie, a jego rozwój był tam tak dynamiczny, że zdumiewa historyków. Szukając wyjaśnienia tego fenomenu afrykańskiego Kościoła, wielu wskazuje na słowa jednego

138 Por. MR 36, s. 20.

139 Por. Sodi, Martyrologium Romanum, s. 15. 
z jego przedstawicieli - Tertuliana, że „nasieniem chrześcijan jest krew męczenników”. Jeśli tak, to ilu ich było? W jakim okresie i z jakiego powodu ponosili najczęściej męczeństwo? Na te i inne pytania poszukiwaliśmy odpowiedzi w Martyrologium Rzymskim, księdze wprawdzie liturgicznej, ale zawierającej również elementy dokumentalne. W wyniku naszych badań udało nam się, jak sądzimy, pogłębić chociaż trochę naszą wiedzę o męczennikach Afryki Północnej, uzyskując przynajmniej ogólną wiedzę o czasie prześladowań, miastach, w których miały one miejsce, o liczbie męczenników i ich statusie społecznym, a przede wszystkim o postawie męczenników w obliczu okrutnej najczęściej śmierci. Informacje te mogą być cenne nie tylko dlatego, że problem męczeństwa jest kluczowy dla zrozumienia starożytności chrześcijańskiej, ale również dlatego, że jest on mało obecny w publikacjach historycznych w naszym kraju.

Słowa kluczowe: Afryka Północna; Martyrologium Rzymskie; męczennicy

\section{Bibilografia}

\section{Źródla}

Acta Scillitanorum, ed. H. Musurillo, The Acts of the Christian Martyrs, Oxford 1972, s. 86-88, tł. A. Bober, OŻ 9, Kraków 1991, s. 240-243.

Augustinus, Epistula 78, PL 33, 267-272.

Martyrologium Romanum, Città del Vaticano 2004.

Mszał Rzymski dla diecezji polskich, Poznań 1986.

Tertullianus, Apologeticum, ed. E. Dekkers, CCL 1, Turnhout 1954, s. 85-171, tł. J. Sajdak, POK 20, Poznań 1947.

\section{Opracowania}

Baus K., Le origini, tł. E. Guerriero, w: H. Jedin, Storia della chiesa, t. 1, Milano 1997. Campenhausen von H., Ojcowie Kościoła, tł. K. Wierszyłowski, Warszawa 1998.

Cichy S., Święci w liturgii, „Anamnesis” 45 (2006) s. 3-4.

Daniélou J. - Marrou H., Dalle origini a S. Gegorio Magno, tł. G.D. Gordini, w: L.J. Rogier - R. Aubert - M.D. Knowles, Nuova storia della Chiesa, t. 1, Torino 1970.

di Berardino A., Cartine geografiche, DPAC III 81-129.

Duval A., „Massa Nigra”. Męczennicy Czarnej Afryki, tł. P. Mikulska, „Ethos” 53-54 (2001) s. 180-191.

Eckmann A., Kult męczenników afrykańskich w pismach św. Augustyna, „Vox Patrum” 30/55 (2010) s. 183-188.

Grzywaczewski J., Chrześcijaństwo na wsi afrykańskiej w okresie patrystycznym, $\mathrm{w}$ : Ewangelizacja w epoce patrystycznej. Zagadnienia wybrane, red. F. Drączkowski - J. Pałucki, Lublin 1994, s. 25-37. 
Jan Paweł II, Ecclesia in Africa, https://opoka.org.pl/biblioteka/W/WP/jan_pawel_ii/adhortacje/ecclesia_africa.html (dostęp: 26.04.2019).

Kumor B., Afryka-Kościół katolicki-Starożytność, EK I 139-143.

Landau M., Na grobie Achillesa, „Wprost” 35 (2004) s. 72-74.

Majcher Z., Historia ewangelizacji kontynentu afrykańskiego w zarysie, „Seminare” 17 (2001) s. 449-475.

Matuszewski M., ,,Martyrologium Romanum” jako księga liturgiczna, „Anamnesis” 45 (2006) s. 42-50.

Scaduto M., Africa: Storia cristiana antica, w: Enciclopedia Cattolica, t. 1, red. M. Scaduto, Firenze 1948, s. 383-398.

Sodi M., Martyrologium Romanum. Znaczenie, walor i aktualność ostatniej posoborowej księgi liturgicznej, t1. Z. Adamiak, „Seminare” 25 (2008) s. 11-21.

Starowieyski M., Męczeństwo, w: Męczennicy, opr. E. Wipszycka - M. Starowieyski, OŻ 9, Kraków 1991, s. 84-144.

Starowieyski M., Z historii wczesnego chrześcijaństwa: Biblia, męczennicy, poganie i inni, Kraków 2015.

Strzelczyk J., Wandalowie i ich afrykańskie państwo, Warszawa 2005.

Wipszycka E. Prześladowania w Państwie Rzymskim, w: Męczennicy, opr. E. Wipszycka - M. Starowieyski, OŻ 9, Kraków 1991, s. 15-83. 


\section{Aneks}

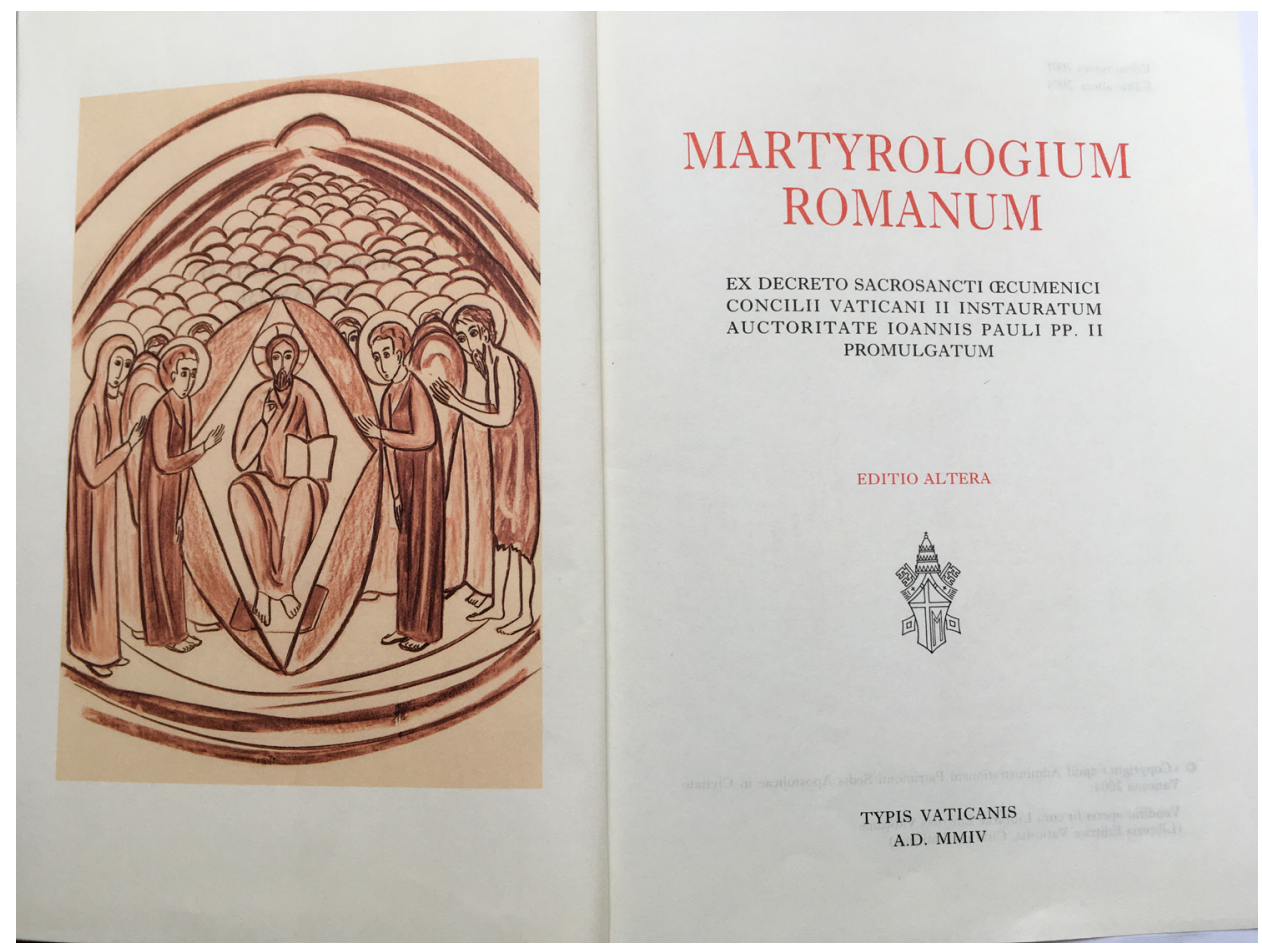

Martyrologium Romanum, Città del Vaticano 2004 (fot. ks. A. Nocoń) 